\title{
EVALUATION OF THE IMPLEMENTATION OF INDONESIA PINTAR PROGRAM IN VOCATIONAL SCHOOL
}

\author{
Syukrul Hamdi $^{{ }^{*}}$, Risky Setiawan ${ }^{1}$, Faridl Musydad ${ }^{1}$ \\ ${ }_{1}^{1}$ Universitas Negeri Yogyakarta \\ Jl. Colombo No. 1, Karangmalang, Depok, Sleman, Yogyakarta 55281, Indonesia \\ *Corresponding Author. E-mail: syukrulhamdi@uny.ac.id
}

\begin{abstract}
The study aims to evaluate a program of channeling educational fund, Program Indonesia Pintar (PIP), for vocational school (sekolah menengah kejuruan or SMK). This research was evaluation research using mix method approach. The evaluation model used was the CIPP model covering context, input, process, and product. The respondents of the study were 702 principals, 125 student's parents, and 15853 students of the SMKs spreading across 29 out of 34 provinces in Indonesia. Data collection techniques used were analysis, survey, interview, observation, and study documentation. The instruments used were analysis sheets, questionnaires, interview guidelines, observation sheets, and the list of related documents. Data analysis techniques used were quantitative descriptive and qualitative and comparing the result with the PIP evaluation success criteria. The results show that the overall PIP implementation runs well with details in aspects: (a) context, the PIP socialization is implemented well, the PIP objectives performance is in the very good category and can ease students' costs in the excellent category; (b) input, the school provides particular staffs executing PIP showing the excellent category; (c) process, the targeted accuracy of most PIP students at SMK states that they follow the provisions. Based on the PIP SMK management role and function, the institute has served well; (d) product, most issues reported of the PIP funds for SMK indicate that the use of the fund by students is suitable with the provision and its management. The current model of the PIP aid funds needs to be advanced, particularly with several aspects unsteady.
\end{abstract}

Keywords: Program Indonesia Pintar (Smart Indonesia Program), vocational school, evaluation, CIPP

How to cite: Hamdi, S., Setiawan, R., \& Musyadad, F. (2020). Evaluation of the implementation of Indonesia Pintar program in vocational school. Jurnal Penelitian dan Evaluasi Pendidikan, 24(1), 102-115. doi:https://doi.org/10.21831/pep.v24i1.32603

\section{INTRODUCTION}

The Republic of Indonesia government through Presidential Instruction No. 7 of 2014 has instructed ministers, heads of state institutions, and heads of local governments to implement Productive Family Program through the Prosperous Family Savings Program (Program Simpanan Keluarga Sejabtera or PSKS), Healthy Indonesia Program (Program Indonesia Sehat or PIS), and Smart Indonesia Program (Program Indonesia Pintar or PIP). To achieve these goals requires proactive measures of institutions and related agencies related to their respective tasks, functions, and authorities in a coordinated and integrated manner to enhance the programs' effectiveness and efficiency. The Ministry of Education and Culture's authority and responsibility are to perform PIP to increase access for six-to-21-year-old children to get educational services to graduate secondary education units and prevent them from dropout tendencies.

PIP, as a national strategic program, is expected to be able to guarantee students to pursue their education until graduating from secondary education and recruit drop-out students or discontinued their education to receive education services. PIP is not only for students in 
school, but also for students at the Learning Activity Studio (Sanggar Kegiatan Belajar), Community Learning Activity Center (Pusat Kegiatan Belajar Masyarakat), Course and Training Institute (Lembaga Kursus dan Pelatihan) and Vocational Training Center (Balai Latihan Kerja), or other non-formal education institutes, by predetermined criteria although there are some issues including those revealed by Saraswati (2017). Several inhibiting factors are identified in implementing PIP policy as a consequence of incompatibility with PIP guidelines, including data used in determining the Smart Indonesia card (Kartu Indonesia Pintar or KIP) prospective recipients still inaccurate, the unpunctuality of time in appealing for PIP funds, the activities of socialization still not optimally conducted, the length of time to verify KIP ownership, and the low awareness of student's guardians as far as what the PIP allocation to be exactly used.

Nowadays, the disparity of school participation among community groups remains quite high. The Gross Enrollment Rate (GER) of economically capable families seems generally higher than the GER of poor families. The increasing educational cost, both direct and indirect costs borne by students becomes a reason for the existence of PIP. Direct costs for students include school fees, books, uniforms, and stationary, while the indirect costs cover personal allowance fees such as transportation and courses. The extremely high educational costs have led to large rates of students dropping out, thus affecting the GER. The amount of PIP targets is reaching out to 20.3 million children/students of school age both in schools/educational institutions under the Ministry of Education and Culture $(17.9$ million children/students) and the Ministry of Religious Affairs (2.4 million children/students). It is expected to be able to cope with the low of GER as well as one of the government's efforts to enhance human lives with better education and skills.

The main point to be implemented in increasing GER is to reduce the dropout rate for secondary education at the Vocational High School (SMK), thus, PIP is implemented by the Directorate of Vocational School Development (Dit.PSMK). PIP is in the form of the educational fund's aid from the government given to students who come from poor or underprivileged families impoverished in funding education. Further, PIP for vocational students is supposed to increase access and interest in student learning as a promotional event to raise the quality of vocational schools. Aid is offered to underprivileged vocational students registered in the Integrated Database. Thus, PIP needs to get support from various parties, especially the government and channeling institutions, and get periodic monitoring and evaluation. Evaluation of PIP for vocational students becomes one of the parameters to achieve the PIP success in the evaluation aspects of context, input, process, and product and outcomes.

The management of the implementation of the Smart Indonesia Vocational Program (PIP SMK) refers to the Regulation of the Minister of Education and Culture No. 9 of 2018 amendment to the Regulation of the Minister of Education and Culture No. 19 of 2016 concerning the technical procedures of the Smart Indonesia Program (PIP). Meanwhile, the objectives of PIP SMK are to (1) increase access for vocational students to obtain educational services until completion of the Vocational secondary education unit to support the implementation of Universal Secondary Education/12-year compulsory education pioneer, (2) prevent students from dropping out or discontinuing their education due to economic difficulties/underprivileged, (3) encourage vocational school students who are dropping out or discontinuing to return getting their education services at school, (4) alleviate personal education costs, and (5) support the completion of 12-year compulsory primary education, for registered students at primary and secondary/equivalent level.

The targets of the PIP SMK recipient priority are (1) vocational school students holding PIP card; (2) vocational students included in the category of underprivileged and/or poor families with special considerations such as (a) vocational school students included in the family participating in the Family Hope Program (Program Keluarga Harapan or PKH) and (b) vocational school students whom their family holds Prosperous Family Card (Kartu Kesejabteraan Keluarga or KKS); (3) vocational school students who are orphans/in social orphanage; (4) vo- 
cational school students affected by natural disasters; (5) vocational school students having physical disabilities, inclusion students, victims of disasters, layoff parents, conflict areas, included convicted families in the prison, having more than three relatives living in the same house; and (5) vocational school students ever studying into group expertise in the fields of agriculture, fisheries, animal husbandry, forestry, and shipping/maritime. Moreover, students included in the prioritized target of the PIP SMK recipients can be proposed with the following conditions: (1) registered as students at school, (2) registered in the Basic Education Data (Data Pokok Pendidikan or Dapodike) of the school, and (3) proposed by the school through the provincial education office to the Directorate of Vocational Development.

\section{RESEARCH METHOD}

Evaluation research was adopted to evaluate the implementation of the Vocational School of Smart Indonesia Program (PIP SMK). It was to obtain further in-depth information on the data collection, detailed illustration presentation, and the description of the real condition in the field in terms of PIP SMK execution. The source of data is processed, compared with the Regulation of the Minister of Education and Culture No. 9 of 2018, then conclusions were drawn and given meaning to be useful for solving problems encountered in the implementation of PIP. Furthermore, the evaluation was focused on five aspects, namely: contexts, preparation (input), process, the result (product,) and impact.

The evaluation research was conducted in five months starting from July to November 2019. It was calculated since the signing of a memorandum of understanding between Directorate of Vocational Development (Dit. PSMK) and Graduate School of Universitas Negeri Yogyakarta (PPs UNY). This research was conducted in several locations, as listed in Table 1.

Table 1. List of Vocational Schools (SMKs)/Research Location

\begin{tabular}{|c|c|c|}
\hline No. & Provinces & Name of SMK \\
\hline 1 & DKI Jakarta & $\begin{array}{l}\text { SMK N } 29 \text { Jakarta } \\
\text { SMK N } 20 \text { Jakarta }\end{array}$ \\
\hline 2 & West Java & $\begin{array}{l}\text { SMK N } 11 \text { Bandung } \\
\text { SMK N } 12 \text { Bandung }\end{array}$ \\
\hline 3 & Central Java & $\begin{array}{c}\text { SMK N } 4 \text { Kendal } \\
\text { SMK N } 1 \text { Musuk Boyolali } \\
\text { SMK N } 1 \text { Karanganyar }\end{array}$ \\
\hline 4 & D.I. Yogyakarta & $\begin{array}{l}\text { SMK N } 2 \text { Depok Sleman } \\
\text { SMK N } 1 \text { Panjatan } \\
\text { SMK N } 1 \text { Kasihan } \\
\text { SMK N } 6 \text { Yogyakarta }\end{array}$ \\
\hline 5 & East Java & $\begin{array}{c}\text { SMK N } 10 \text { Malang } \\
\text { SMK N } 1 \text { Ampel Gading }\end{array}$ \\
\hline 6 & Banten & $\begin{array}{l}\text { SMK N } 4 \text { South Tangerang } \\
\text { SMK N } 9 \text { Tangerang }\end{array}$ \\
\hline 7 & Bali & $\begin{array}{l}\text { SMK N } 2 \text { Sukawati } \\
\text { SMK N } 5 \text { Denpasar }\end{array}$ \\
\hline 8 & South Borneo & $\begin{array}{l}\text { SMK N } 2 \text { Banjarmasin } \\
\text { SMK N } 2 \text { Banjarbaru }\end{array}$ \\
\hline 9 & South Sulawesi & $\begin{array}{l}\text { SMK N } 3 \text { Makassar } \\
\text { SMK N } 9 \text { Makassar }\end{array}$ \\
\hline 10 & South Sumatra & $\begin{array}{l}\text { SMK N } 3 \text { Palembang } \\
\text { SMK Utama Bakti }\end{array}$ \\
\hline 11 & West Nusa Tenggara & $\begin{array}{l}\text { SMK N } 1 \text { Janapriya } \\
\text { SMK N } 1 \text { Keruak }\end{array}$ \\
\hline
\end{tabular}




\section{Research Respondents}

As explained in the data collection, there were two types of respondents recruited, namely using online and offline methods. Having been collected online, the data were then verified to the respondents in offline. The number of respondents collected using online and offline methods are listed in Table 2.

Table 2. Total and List of Respondents

\begin{tabular}{|c|c|c|c|}
\hline \multirow{2}{*}{ No. } & \multirow{2}{*}{ Research Respondent } & \multicolumn{2}{|c|}{ Total } \\
\hline & & Online & Offline \\
\hline 1 & The Principal & 702 & 25 \\
\hline 2 & The PIP recipients of student's parents & - & 125 \\
\hline 3 & PIP student recipients & 15853 & 625 \\
\hline & Total & 16554 & 775 \\
\hline
\end{tabular}

\section{Data Collection Techniques and Research Instruments}

Data collection techniques employed were analysis, survey, interview, observation, and documentation. Besides, there were several instruments available such as a sheet of study, questionnaire, interview guidelines, observation sheet, and list of documents needed. The sheet of the study was employed to collect data regarding the congruence of the PIP recipient target. The survey technique employing a questionnaire was adopted to gather data needed to answer all of the research questions. Interview guidelines were used to disclose the program recipient's perception of PIP services, funds, and the employment of funds. Observation sheets were utilized to observe the recipient's implementation and the congruence with the program. The list of documents was used to compile secondary data needed, for example, the KIP, Determination of Decree, other documents. In detail, the type of data needed and the data collection techniques employed can be retrieved in Table 3.

Table 3. The Data and Instrument

\begin{tabular}{|c|c|c|c|}
\hline No & Aspects & Data Needed & $\begin{array}{l}\text { Instrument Used } \\
\end{array}$ \\
\hline 1 & Context & $\begin{array}{c}\text { Socialization } \\
\text { The readiness of recipients } \\
\text { The objectives of PIP SMK } \\
\text { The supportive capacity of community }\end{array}$ & $\begin{array}{c}\text { Questionnaire and documentation } \\
\text { Observation, questionnaire, documentation } \\
\text { Questionnaire and documentation } \\
\text { Questionnaire and documentation }\end{array}$ \\
\hline 2 & Input & $\begin{array}{c}\text { The recipient target of PIP SMK } \\
\text { The availability of human resource in administrating PIP SMK } \\
\text { The management input of PIP SMK }\end{array}$ & $\begin{array}{l}\text { Questionnaire and documentation } \\
\text { Questionnaire and documentation } \\
\text { Questionnaire and documentation }\end{array}$ \\
\hline 3 & Process & $\begin{array}{l}\text { The accuracy of PIP recipient target in the school level } \\
\text { The number of recipients who have received the PIP fund } \\
\text { The number of recipients who have not received the PIP fund } \\
\text { The precise number of fund received by students } \\
\text { The punctuality of channeling the PIP SMK financial aids } \\
\text { The role and function of the involved institutions }\end{array}$ & $\begin{array}{l}\text { Questionnaire and documentation } \\
\text { Questionnaire and documentation } \\
\text { Questionnaire and documentation } \\
\text { Questionnaire and documentation } \\
\text { Questionnaire and documentation } \\
\text { Questionnaire and documentation }\end{array}$ \\
\hline $\begin{array}{l}4 \\
.\end{array}$ & Product & $\begin{array}{l}\text { The congruence of the use of the PIP SMK aid fund } \\
\text { PIP report } \\
\text { The level of achievement of PIP SMK recipients }\end{array}$ & $\begin{array}{l}\text { Questionnaire and documentation } \\
\text { Questionnaire and documentation } \\
\text { Questionnaire and documentation }\end{array}$ \\
\hline
\end{tabular}

The data collection was carried out in two ways: online and offline. Online data collection was done by issuing an instrument filling order announced through the Dit.PSMK website on the Takola system. The school filled in the instrument through the link provided on the Takola website. Furthermore, data collection offline was by visiting the sample schools listed in Table 1 and filling out as well as sending the instruments online. In addition, the visit was aimed to verify the data that had been sent online and to extract data in more depth. 


\section{Data Analysis Techniques}

A number of techniques had been designed to analyze the data, namely the quantitative descriptive and qualitative approach by employing the percentage and central tendency. The result of the analysis was then described and displayed in the form of a table and figure or graph. Meanwhile, the analysis of data qualitative was a well-established approach to clarify, find, and develop the terms which were unably reached out through the quantitative data.

\section{FINDINGS AND DISCUSSION}

\section{Findings}

This study was designed to evaluate the Program of Smart Indonesia (PIP) for Vocational School (SMK) by adopting the CCIP evaluation model which include several aspects, namely (1) evaluation of context aspect, (2) evaluation of input aspect, (3) evaluation of process aspect and (4) evaluation of product aspect. This evaluation research was initially set out by describing the characteristic of evaluation result data, thus it was presented sequentially based on the aspects of the CIPP evaluation model. Having been presented, the problem or the obstacle that emerged during the implementation of PIP SMK in 2019 was included.

The sources of information were gathered from students, student's parents, the viceprincipal, and the staff of PIP SMK management. It was then presented derived from the result expected or based on the research question and the scope of the study begun with the comprehensive analysis, problem identification, and model evaluation of PIP SMK implementation services. The data of Vocational Schools where there include student recipients of PIP funds is presented in Figure 1.

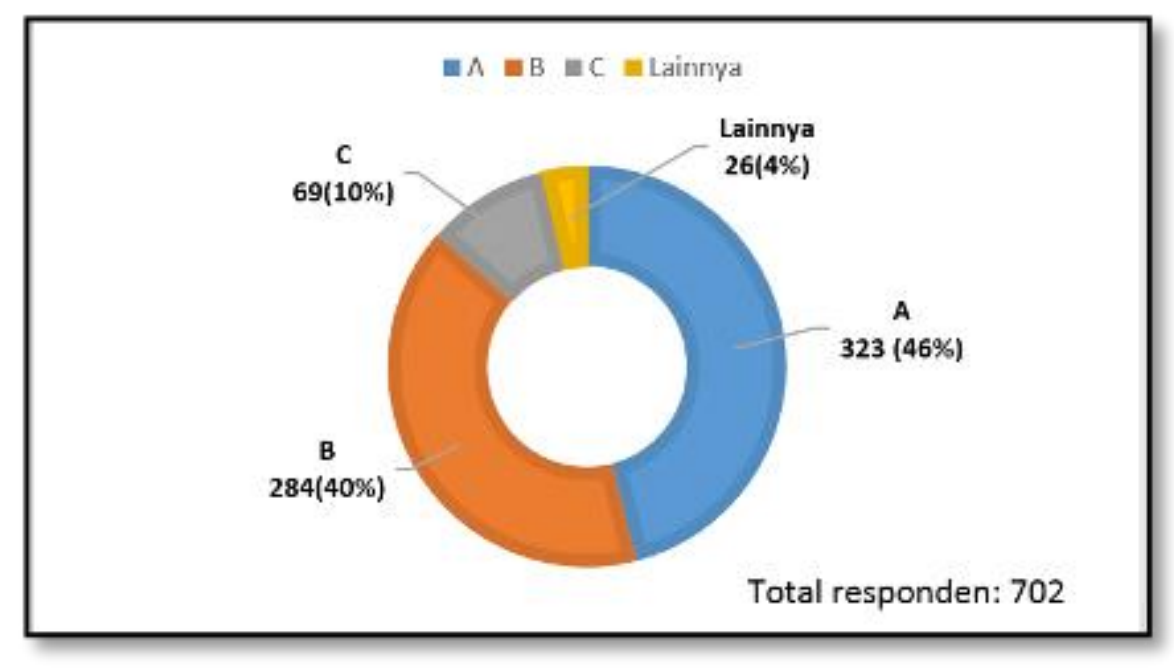

Figure 1. Distribution of PIP Recipient's in SMK Accreditation

Figure 1 shows that there are 702 principals of vocational school (SMK) who completed the questionnaires regarding the execution of the Indonesia Smart Program fund. Description of the data presents that $46 \%$ of vocational schools with the amount of 323 (SMKs) has been accredited with A category, while the percentage of vocational schools accredited B was $40 \%$ with the amount of 284 vocational schools (SMKs). Besides, the number of vocational schools accredited C was 69 SMKs, approximately 10\%. Lastly, the data of SMKs which had not been accredited reaching out $4 \%$ or amount 26 vocational schools.

Respondents are recruited nationally from the western of Sumatra to eastern Papua island. A number of respondents are predominantly from regencies/cities that have generally 
been reached by the internet. The highest number of respondents was the provinces of West Java, then East Java, followed by D. I. Yogyakarta, then North Sumatra and Bali as well as Aceh and the other provinces. The time given to fill instruments online was one month but as of 31 October 2019 data were collected in 29 provinces while five other provinces had not sent data such as West Papua Province, North Maluku, Maluku, West Sulawesi, and North Sulawesi.

Based on the characteristic of data source, the researchers felt interested in investigating the depth information regarding the notion why certain provinces possibly to send answers, it turned out that only a few respond to fill in the evaluation instruments of the implementation of PIP SMK such as Central Java, Banten, and even DKI Jakarta, which incidentally they include metropolitan cities and the capital city whose area were already much affordable by the internet. This required a study of why the region seemed less responsive to the circular of the Directorate of PSMK.

The implementation of PIP SMK has received appreciation from many parties, especially student's parents' recipients of aid funds. They revealed that the fund of PIP SMK was sufficient to help alleviate the personal costs of education even though it had not been able to cover the need for personal education costs for one semester. Table 4 presents data on the realization of the PIP SMK Implementation based on the CIPP evaluation model seen in aspects of context, input, process, and product.

Table 4. The Evaluation Result of PIP SMK Implementation in 2019 Nationally

\begin{tabular}{ccc}
\hline Aspect & Indicator & Score (\%) \\
\hline Context & Socialization & 88.00 \\
& The objectives of PIP SMK & 85.50 \\
The readiness of recipients & 87.50 \\
Input & The supportive capacity of community & 91.67 \\
& The recipient targeted of PIP SMK & 88.17 \\
& The availability of Human Resource in administrating the PIP SMK & 75.00 \\
The management input of PIP SMK & 87.50 \\
& Rates & 75.00 \\
& The accuracy of PIP recipient target in School Level & 83.56 \\
& The punctuality of channeling the PIP SMK financial aids. & 87.50 \\
The accuracy of the amount received by students & 68.75 \\
& The role and function of the involved institutions. & 75.00 \\
& Rates & 75.00 \\
& The congruence of the use of PIP SMK aid fund & 76.56 \\
& PIP report & 82.14 \\
& The level of achievement of PIP SMK recipients & 75.00 \\
& The level of behavior changes of PIP SMK recipients & 50.00 \\
& Rates & 77.78 \\
& Total of Rate & 71.23 \\
& & 78.15 \\
\hline
\end{tabular}

As can be seen from Table 4, the accomplishment of PIP SMK implementation in 2019 amounted to $78.15 \%$ with a good category. Of the five aspects evaluated, the highest score was in the aspect of context with a percentage of $88.17 \%$, indicating that the PIP SMK is an important program. The socialization and direction of the program objectives have been well-implemented managed by the staff administer of the PIP program starting from the central government, in case of the Directorate of PSMK, then the regional government namely Provincial Education Office, as well as the spearhead of program implementers such as schools. The readiness of beneficiaries had been very good. It was reflected in the existence of proposals agreed with their designation and the requirements as well as the prioritized target 
of PIP SMK recipients. The higher supportive capacity of various parties also contributed to a successful program reflected in the enthusiasm of student's parents supporting the program.

The next aspect of the evaluation was input amounted for $83.56 \%$ with a very good category. It indicated that the administers had been successfully preparing the implementation of the program in terms of the target recipients, the availability and adequacy of the administration, and its input management. The most preferable input aspect was the availability of human resources who were considered sufficient and able to manage the program well. In fact, in most of the schools was formed a specialized staff to handle the program of PIP SMK.

Turning to the aspect of process, there was a marked decrease comparing to the prior two aspects with a percentage of $76.56 \%$ in a good category. The leading indicator of this aspect was the accuracy of the targeted recipients who fitted the requirements such as underprivileged families, poor families, and orphan students whose parents are unemployed, and other criteria congruent with the fund recipient. However, the intended indicator had not yet been optimal because there were still changes in the data and the differences between the proposed data and the data contained in the decree. It was consequently leading to create its difficulties for the administrative staff get confused and made social jealousy due to the fact that many students who should be eligible for the fund, but they were not required because of the decree even there certain school claimed to get the decree but it was not for students in that school.

Changes and differences in the data might allow the integrated database asymmetry among the proposed and specified as well as the data asymmetries in Basic Education Data (Dapodik) and data in the Ministry of Social Affairs. This required policyholders to retrace and synchronize data to be essential. Another indicator to put more attention was the inaccurate disbursement of funds in terms of both the time of disbursement and the amount received by students. The indicator score reached out $68.75 \%$ in the sufficient category and the accuracy of the number obtained a score of $75.00 \%$ in the good category, It indicated that the administers, especially the channeling bank, need to be rechecked as to what caused the delays and inaccuracies in the amount received. The result of the interviews in the field in the administrative fulfillment was considered to be complicated and draining energy and the duration of the disbursement process were the major cause of the disbursement time delay and inaccurate amounts received. Even up to November 16, 2019, based on the results of verification in the field, there were still funds that could not be disbursed.

Moreover, the role and function of vocational schools in administrating the implementation of the PIP SMK program obtained a percentage of $75.00 \%$ in the good category. It indicated the role and function of the school as a program administrator that had sought to carry out the mandate given. Changes and differences in data became factors that reduced the role and function of schools in the success of this program. In addition, the process of disbursement of funds was still considered to be burdensome to the administrators and recipients of aid. Based on interviews with staff, some suggested that the distribution of funds need to be channeled through PT. Pos Indonesia. The one reason is that several post offices in each sub-district have fewer queues compared to disbursement arrangements at banks.

Moving on forward to the aspect of product, the accomplishment of PIP SMK implementation was a good category amounted to $71.23 \%$. The indicator of aid funding use was in the very good category with a score of $82.14 \%$. Although the result of interviews with parents, they claimed it was used for basic needs such as paying for electricity, water, paying motorcycle tax and buying groceries, even to donate a wedding. Thus far, the use of PIP aid funds had been categorized successfully to alleviate the need for personal education costs for the recipient even though it was considered insufficient to meet personal educational needs in one semester. In addition, to specialized programs such as agribusiness and agro-technology, technology, and engineering including aircraft engineering, fishing techniques need a higher personal education allowance, and also such the concentration study of energy, maritime, and mining was no exception. 
The other indicator of product aspects was the completeness of reporting on the implementation of SMK PIP made by schools. The result of the study in the data table above shows that only up to $75 \%$ had made a report on the implementation of SMK PIP. On the other hand, around $25 \%$ of other schools had not yet been completed as a consequence of the disbursements of funds that had not yet been received by the recipient students. This factor of disbursement delayed was an inevitable effect, causing other problems such as delaying in making reports, and schools should cover in advance for the needs of school operations that had agreements with recipients using PIP vocational funds.

This educational funding program for vocational aimed at reducing the personal cost of education with a gradual percentage reaching out $63.89 \%$ even though it is in a fairly good category. It was quite considered to be successful because the impact of PIP SMK indirectly affected the students' attainment and behavior. The change in the level of success before and after the PIP Vocational Achievement of ordinary students was proved with a score of $50.00 \%$. It indicated half of the score was quite a good category. As for the behavioral indicator, it showed an interesting case when compared to the citizen perceptions towards the vocational students in the past few decades. It was assumed that vocational students' fame was negatively referring to such frequent brawl, underachievement, brutality, and other negative stereotypes. A behavior score at $77.78 \%$ was in a good category, only the sub-indicator such as frequent cheating, and did not attend the ceremony which remained more intensive attention.

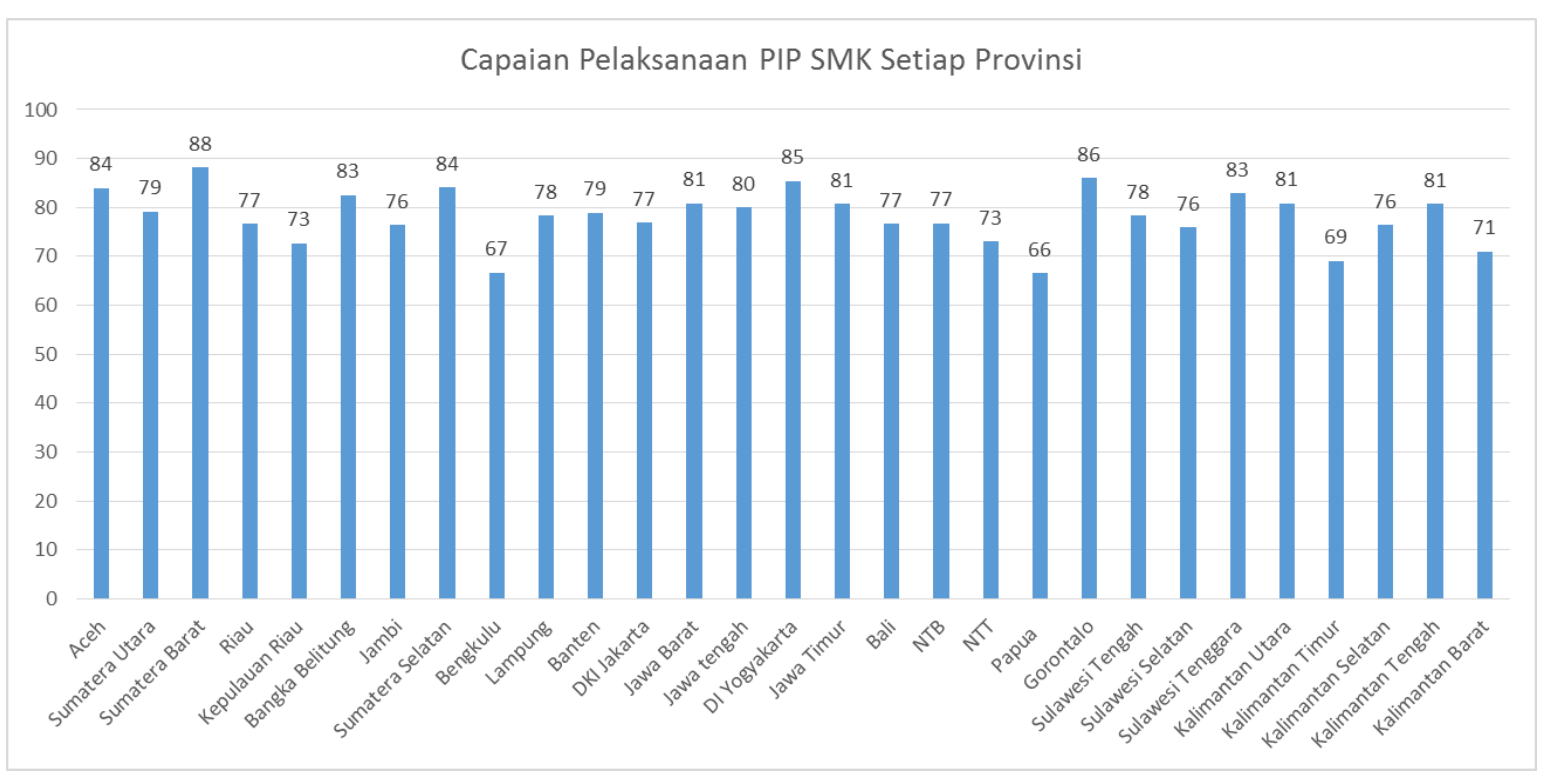

Figure 2. The Accomplishment of PIP Implementation Derived from the CIPP Evaluation Model in Vocational Schools in Each Province

Based on Figure 2, it showed that the accomplishment of the implementation of PIP SMK in each province was obtained a national average at $78.15 \%$. The obtained score could be interpreted that the implementation of PIP SMK in Indonesia had been applied well, meaning that all SMKs in Indonesia had carried out the mandate given through the roles and functions. However, it could also be seen in the figure that there were several provinces getting scores below the national average. It might occur due to several factors inhibiting the implementation of the PIP which will be explained in the next discussion.

If the top 5 and the bottom 5 biggest are ranked, the following information is obtained. Firstly, the first rank with the highest score included West Sumatra province at $88 \%$, the second position was Gorontalo province at $86 \%$, the third was the province of D. I. Yogyakarta 
getting at $85 \%$, then the fourth rank was two provinces, called Aceh and South Sumatra province, at 84 . And the last with reaching $83 \%$ were Bangka Belitung and Southeast Sulawesi provinces. Furthermore, several 18 provinces reached the national average of 78.15 or $63 \%$ of 29 provinces.

Turning to the fifth-lowest rank, they were the province of Papua at $66 \%$, Bengkulu with a score of $67 \%$, East Kalimantan at $69 \%$, then the fourth was the province of West Kalimantan $71 \%$ and the last was two provinces with the same score of $73 \%$ called Riau Island and East Nusa Tenggara province. In addition, 11 provinces were below rates of the national average of 78.15 or $37 \%$ of 29 provinces.

\section{Discussion}

The PIP grant aims to meet the basic needs of personal educational allowance such as books and stationery, purchasing the school uniforms and equipment, finance transportation to schools, additional practice/apprenticeship fees, courses, and student allowances. It needs to be done by the government through the Directorate of PSMK so vocational schools can develop their learning optimally and support the developments of science and technology. The discussion focuses on the results of the evaluation, mainly related to (1) a comprehensive evaluation including the context, input, process, product, and impact, and (2) the results of identification and analysis of issues and obstacles on the distribution and disbursement of SMK PIP funds.

The results of the study indicated that the implementation of the PIP program was successful with a national rate score of $78.15 \%$. An unexpected result was that five provinces did not send the data and did not complete the questionnaires. They are West Papua, Maluku, North Maluku, North Sulawesi, and West Sulawesi. The provinces which had the most success in organizing the PIP program were West Sumatra Province with a score of $88 \%$, the second was Gorontalo with a score of $86 \%$, the third was Yogyakarta with a score of $85 \%$, then in the fourth rank was positioned with two provinces with the same score by $84 \%$, the province of Aceh and South Sumatra. The last was ranked by two provinces the same score of $83 \%$, including the province of Bangka Belitung and Southeast Sulawesi. Furthermore, 18 provinces were above the national average with 78.15 or $63 \%$ of 29 provinces. The fifth provinces categorized successfully in implementing the PIP program are since they strongly adhere to the PIP Program Implementation Guidelines.

The result of the context evaluation was a good category with a rating score of $78.15 \%$. According to respondents (in case of the Head of Vocational School), the PIP program was increasingly contributed to the educational demand of the recipient. In another case with the input evaluation, the result showed that the target indicator of PIP SMK recipients was a very good category getting at $83.56 \%$. Based on interviews with the principal of the Vocational School, the low score of the PIP recipient target indicator because the names of students who appeared in the Decree of the PIP beneficiary list were not all the same as those proposed by the school. Also, the input aspect had an indicator that was included in the good category (nearly to not very good), which was the input indicator of the PIP SMK management. According to the head of the vocational school, it was caused by the PIP program's socialization that had not yet been optimum. The socialization was still held in a conventional manner such as spoken announcements in class so there were $4.63 \%$ of students who claimed the school had not done the socialization and $15.20 \%$ of students who said they did not know. Socialization was an essential part. It is supported by the prior study done by Setyawati (2018) revealed that several supporting factors influenced the effectiveness of the Indonesia Smart Card (KIP) program including regular information promoted by to school and also online mode.

In the process aspect, The indicator of the PIP recipient targeting accuracy at the school was categorized in the excellent category at 87.50, while the other two indicators included a good category. Each indicator had a score of 75 , and the other indicators were quite a good 
category at 68.75 . The indicator which had a fairly good category reaching at 68.75 regarding the punctual disbursement of PIP vocational aid funds. It was caused by the bank in which the aid of the PIP fund was taken far from where students stayed, so several students asked staff officers to get it. Besides, it was quite occurred that the disbursement fund should go back and forth to the bank, and unnecessarily the cash could be received.

The indicators categorized as good (not very good) were the accuracy of the number of funds received by students. The result of interviews with students, student's parents, schools, and banks obtained information in terms of no deductions by the school or from the bank. The amount of money received by students was around $\mathrm{Rp} \mathrm{1,000,000} \mathrm{(one} \mathrm{million} \mathrm{rupiahs)}$ each year. The type of aid was quite meaningful for students whose practice did not require a fee, another case for students whose practice required a lot of costs, such as food and fashion concentration, it categorized very less. Therefore, it would be precise if the amount of aid was not the same but adjusted for the competency of the expertise taken by students.

The aspect of product has four indicators. One of them is the indicator of the congruence for the PIP fund use and the indicator of the PIP report. The score obtained by the congruence for the use of PIP funds reached 82.14 which meant that the use of the funds was based on the guidelines. Nevertheless, there were still respondents (students) who said that the PIP aid fund was partly to purchase credit and given to his parents to buy groceries. Meanwhile, the indicator of the PIP report was still categorized as good (not very good) with a score of 75 . It might be caused only about $75 \%$ of SMKs to make the PIP report. This score of the PIP report increased when the government quite frequently checked the completeness of the PIP fund report.

The third indicator was the medium category with a percentage of 50, while the fourth indicator was a good category with a score of 77.78. It did not significantly influence the PIP aid fund on learning achievement. However, it has few effects on students' negative behavior; for example, according to the perception of students, they were more disciplined than ever and rarely persuaded their friends to skip school.

Conceptually, the Smart Indonesia Program through The Card of Smart Indonesia (KIP) is quite clear, including the target recipients. This is because the legal basis for implementing the PIP program is coherent, particularly: (1) Presidential Instruction No. 7 of 2014, which includes mandating the Smart Indonesia Program (PIP) to the Ministry of Education and Culture to prepare a Smart Indonesia Card (KIP) and distributing the Program of Smart Indonesia (PIP) funds to students whose parents are unable to pay for their education, and (2) Regulation of the Minister of Education and Culture No. 9 of 2018 as amendments to the Regulation of the Minister of Education and Culture No. 19 of 2016, concerning the technical guidelines for the Smart Indonesia Program. However, at the level of implementation, it seems quite problematic, both regarding the validity and accuracy of the data employed as the basis for KIP and the method of distribution.

The result of evaluation in 29 provinces show that in general, the PIP implementation had run quite well, which overall reached $78.15 \%$. It can be interpreted that the implementation of the PIP financial aid is worth continuing. However, a wider range of problems occurred need to be sought for a solution. Among these problems are as follows; firstly, the problem of the accuracy of the data is used for the determination of PIP recipient candidates. This issue occurred since the data employed came from the National Team for the Acceleration of Poverty Reduction (Tim Nasional Percepatan Penanggulangan Kemiskinan or TNP2K), whose survey was conducted in 2011 so the data used had expired, and the profile of students and their parents had altered a lot. Therefore, it is questionable if there are vocational students who have graduated to get KIP. On the contrary, incapable students do not get PIP financial aid.

The inaccuracy of the data used in determining the prospective PIP recipients ultimately emerged a sense of injustice in the community and a domino effect. It led to many underprivileged students who did not receive it, but students who did not quite need it such as graduated 
students, or privileged families whose parents are capable, receive financial aid. Thus, the inaccuracy in the data employed to determine PIP beneficiaries had made some PIP aid was not on target. It was confirmed by the results of research by Kusbianto et al. (2018) that the implementation of PIP still had several obstacles which resulted in not being targeted on the disbursement of the education aid program.

In addition, the imprecise target of PIP beneficiaries was also large due to the lack of mandate of government officials at the lowest levels, such as heads of neighborhood and village heads. The cash (Bantuan Langsung Tunai or BLT) financial aid conducted in the prior administration period was also allegedly experiencing a lot of inaccurate targets, which were caused by the insecurity of government officials at the lowest level.

The solutions offered to cope with the problem are: (1) the need to combine data from TNP2K with Dapodik to ensure data accuracy. The method is currently being implemented, so that the distribution of PIP funds becomes progressive, even reaching more than $90 \%$; and (2) increasing the supervision in the determination of KIP recipient targets, to the maximum extent possible involve the community, and also non-governmental organizations so the mechanism is more transparent and accountable. Thus, the government was obligated to formulate the provision of access for the community and non-governmental organizations to be engaged in the supervision of KIP distribution and the determination of prospective PIP recipients.

Secondly, issues related to distribution and disbursement of PIP financial aid. The method and mechanism for the distribution of PIP funds turned out to have many problems. For instance, PIP fund channeling institutions; So far, the banks are state-owned called BNI (Bank Nasional Indonesia) and BRI (Bank Rakyat Indonesia). These two state-owned banks (Badan Usaba Milik Negara or BUMN) are seen as more appropriate, as they are more accountable. Notwithstanding, affordability by PIP recipients, especially in three Ts (Terluar, Terpencil, dan Tertinggal) regions called Outermost, Backward, and Frontier still has many limitations. Hence, the alternative suppliers should be sought, especially for students in the three Ts region, for example by utilizing the Post Office, or by opening a temporary service office that was assigned particularly in the distribution of PIP funds.

In order that the directors of state-owned banks have a high commitment to expedite the distribution of KIP, their achievements need to be appreciated as the directors' work performance even though it is social work. Another suggested form is that KIP distribution be funded by bank Corporate Social and Responsibility (CSR) funds so that the bank can recruit special KIP distribution personnel, without disrupting the banking business. By fixing this distribution model, KIP is expected to be received on time without disrupting the performance of the supplying banks.

As shown in the Indonesian Network for Education Watch (Jaringan Pemantau Pendidikan Indonesia or JPPI) findings during the period of July 2017-February 2018, there were a number of reports on KIP complaints. Of the 112 total complaints, 32 of them were related to the unequal distribution in the outermost, foremost, and backward regions, as well as other marginal regions. In addition, 30 complaints as the ground that KIP distribution was not on target, 27 reports of KIP recipients were difficult to disburse and, ten reports of delays, eight complaints associated with real-time data, and no public involvement with five reports.

The PIP program can be one solution to overcome the issue of dropping-out students. However, the practical application has not yet been fully realized (Rochmat Wahab). According to him, several factors are causing it. Firstly, the use of PIP funds should be strictly monitored, to increase family spending particularly was avoided. Secondly, the PIP funds had not fully met the learning needs of vocational school students since the budget needed for them is relatively larger. Thirdly, children who drop out of school were not solely caused by economic problems, but some might be caused by services that did not reach their demands. For this reason, PIP should be oriented towards remedial programs that help those who have difficulty accessing the learning process. Thus, you will avoid dropping out of school. 
PIP financial aid is expected to reduce dropout rates, yet it has been less successful in increasing student participation rates. The reason why to encourage children in participating in the Learning Activity Studio (SKB)/Community Learning Activity Center (PKBM)/Institution of Course and Training (LKP)/Job Training Centers (BLK) or other non-formal education units is not easy. The majority of such children who are not willing to go to school because they whose ages do not include to take education in formal schools, or they already enjoy working at school age (BeritaSatu.com, 2020).

A report of the Indonesia Corruption Watch (ICW) considers that the Indonesia Smart Card (KIP) program is ineffective and many unreliable targets. Monitoring is carried out to see three aspects, such as Right on Target, Timely Distribution, and Right Disbursement (Hidayat, 2018). Laiz also stated that the results of this monitoring showed that there were still many (41.9 percent) poor people who were not registered as KIP/PIP participants. It was caused by the data employed for the KIP/PIP program was still inaccurate. Some of the KIP/PIP funds had been used to finance students' personal needs (personal costs and fees/donations to the schools). However, most of these funds had not been used for educational purposes.

Apart from all the issues and some suggested solutions described, the PIP Program is good and needs to be continued. The PIP program is a service program which is more affirmative so the benchmarks of success are the quality of services which can satisfy customers (target groups), such as PIP recipient's target accuracy, timeliness of distribution, ease of accessing information for PIP recipients, the accuracy of the amount of financial aid, and the precise of the use of PIP funds that it can reduce the ineffectiveness of the PIP funding aid, in particular, does not become a concern in improving achievement and student attitudes.

Based on the above description, it confirms that the implementation of the Indonesia Smart Vocational High School Program (SMK PIP) in 2019 has generally been applied well and has successfully fulfilled the four main objectives so that the SMK PIP program needs to be continued in the coming years with a few revisions. This was confirmed by Ilham and Soeharto (2018) who stated that the results of the evaluation study of the implementation of PIP in SMK Negeri 3 Wonosari were categorized as good in terms of school readiness, implementation process, the use of the financial fund, factors affecting PIP.

There were four major objectives of why the PIP should be continued, namely (1) increasing access to education, (2) preventing students from dropping out of school, (3) encouraging dropped-out students to return to school, and (4) alleviating personal educational needs have been met especially the first to third proven goals of increasing the gross enrollment rates (GER) in each province and decreasing dropout rates in each province. Nevertheless, the goal of number 4 seems that it still needs a deeper study because the expertise program in Vocational High School is increasingly high in its variation which impacts the educational funding needs of each program and the different skill competencies. Some require high costs such as the competence concentration in hospitality, aeronautical engineering, energy and mining, nursing, and others. On the other hand, some with the aid of PIP Vocational School have reduced or mitigated such as the expertise of Business and Management and ICT.

In the following aspect of context, several institutions involved such as schools, Provincial Education Offices, village, and sub-district governments, have played a good role in efforts to support program implementation and monitoring. The support is reflected in the efforts to socialize the PIP SMK to prospective recipients, a serious managerial with a special team managing the PIP, and reporting on the distribution of PIP SMK financial funds.

In the aspect of input, the synchronization of data between the Integrated Database managed by the Ministry of Social Affairs and the Basic Education Data (Dapodik) managed by the Ministry of Education and Culture is the key to the success of the PIP program, particularly for the accuracy of targets and the congruence of the received aid funds. Due to the implementation of the PIP SMK, there are still changes and differences in the data set through the Decree, causing inaccuracies in receiving PIP SMK funds. 
The notion regarding a special team of PIP management provided by schools is a brilliant idea to meet the precise distribution of PIP SMK financial aid. Besides, most recipient students also have KIP, making it easier for schools to record and propose to the government because schools do not have the authority to change the fecree which has been set. Even though, it is still quite often to find the requiring students who are ineligible to get the aid.

In the aspect of process, there are obstacles in which the biggest of them are the delay and inability to channel PIP aid funds. Varied disbursement times have a domino effect, for example, schools bear of the operational costs at first. Then, the impact of anxiety and uncertainty about the disbursement of funds becomes too late. The issue of the deduction of the aid funds also became its constraint. Schools, provincial education offices, and the Directorate of PSMK should be able to reprimand and curb the disbursement of aid funds.

In the aspect of product evaluation, the congruence of the beneficiaries was largely in line with the stipulated decree. The use of financial aid is also widely related to its designation, namely to ease personal education costs such as stationery, uniforms, practice cost, course fees, purchase of bags, school shoes, and others. However, there is still abuse in employing the aid funds as evidenced by the use of PIP SMK financial aid for other purposes such as buying groceries and paying household needs such as paying for electricity, water, motor vehicle tax. Community perception, especially the students' parents receiving PIP SMK funds, considers that these funds are the same as other financial aid in the PKH program, PKS, which may be used for daily needs. It is reinforced by the results of the research by Yusup et al. (2019) that PIP recipient students felt the benefits of the Smart Indonesia Program implemented in schools. However, the funds received each year are still lacking and have not been able to meet all the needs of students. The PIP should be carried out well. It is in line with the study conducted by Cahyaningsih (2018) revealed that the PIP program can support the 12-year compulsory education program of the government.

\section{CONCLUSION}

This evaluation study adopting the CIPP model has investigated that generally the implementation of the Smart Indonesia Program (PIP) in vocational high schools (SMK) in 2019 in 29 provinces was going well, the national rate score is $78.15 \%$. It is interpreted that the implementation of the PIP program is worth continuing. In the context aspect, PIP socialization has been carried out well, the accomplishment of PIP objectives in the category is very good, and has been able to ease the personal costs of PIP recipients. In the input aspect, the vocational schools have provided staff officers who specifically administrate the PIP, yet the problem of the accuracy of the data employed for the determination of prospective PIP recipients seems to inaccurate and has expired. Therefore, many vocational students who had graduated received the card of PIP (KIP), while underprivileged students did not get the fund through the PIP card. In the aspect of the process, the accuracy of the PIP recipient's target is under the provisions, namely the Regulation of the Minister of Education and Culture No. 9 of 2019. The role and function of the PIP SMK administration staff officers have been functioning well. In the aspect of product, the use of PIP funds by recipients is derived from the provisions where the students are to help the needs of students' education costs. The effectiveness of PIP management has been going well, amounted to $75 \%$ which have reported the PIP SMK funds.

\section{REFERENCES}

BeritaSatu.com. (2020). PKBM: Jendela ilmu di wilayah 3T. BeritaSatu.Com. https://www.berita satu.com/nasional/578426/pkbm-jendela-ilmu-di-wilayah-3t

Cahyaningsih, R. I. (2018). Pendistribusian Kartu Indonesia Pintar. Didaktik: Jurnal Ilmiah PGSD STKIP Subang, 4(1), 147-162. https://doi.org/10.36989/didaktik.v4i1.70 
Hidayat, F. (Ed.). (2018). ICW sebut program Kartu Indonesia Pintar salah sasaran. WartaEkonomi.Co.Id. https://www.wartaekonomi.co.id/read183344/icw-sebut-progra m-kartu-indonesia-pintar-salah-sasaran

Ilham, M., \& Soeharto, S. (2018). Evaluasi pelaksanaan Program Indonesia Pintar (PIP). Jurnal Pendidikan Teknike Elektro, 8(5), 399-409. http://journal.student.uny.ac.id/ojs/index. $\mathrm{php} /$ elektro/article/view/13549

Kusbianto, D., Hamdana, E. N., \& Fahreza, D. D. (2018). Sistem pendukung keputusan prioritas calon penerima Program Indonesia Pintar pada siswa sekolah menengah pertama menggunakan metode TOPSIS. Jurnal Informatika Polinema, 4(2), 101-108. https://doi.org/10.33795/jip.v4i2.153

Presidential Instruction No. 7 of 2014 on the Implementation of Prosperous Family Savings Program, Smart Indonesia Program, and Healthy Indonesia Program to Construct Productive Family, (2014).

Regulation of the Minister of Education and Culture No. 19 of 2016 on the Smart Indonesia Program, (2016).

Regulation of the Minister of Education and Culture No. 9 of 2018 on Program Indonesia Pintar, (2018).

Regulation of the Minister of Education and Culture No. 9 of 2019 on the Amendment of the Regulation of the Minister of Education and Culture No. 11 of 2018 on the Working Organization and Procedure in the Ministry of Education and Culture, (2019).

Saraswati, L. N. (2017). Implementasi kebijakan Program Indonesia Pintar (PIP) pada jenjang sekolah dasar di Kecamatan Sungai Pinang Kota Samarinda. EJournal Administrasi Negara, 5(4), 6737-6750. https://ejournal.ap.fisip-unmul.ac.id/site/wp-content/uploads /2017/11/JURNAL (11-03-17-07-12-36).pdf

Setyawati, S. (2018). Efektivitas program Kartu Indonesia Pintar (KIP) bagi siswa SMK di Kecamatan Jeruklegi Kabupaten Cilacap (Studi Permendikbud No. 12 Tabun 2015 tentang Program Indonesia Pintar). Thesis. Institut Agama Islam Negeri (IAIN) Purwokerto, Purwokerto.

Yusup, W. B., Ismanto, B., \& Wasitohadi, W. (2019). Evaluasi Program Indonesia Pintar dalam peningkatan akses pendidikan di sekolah menengah pertama. Kelola: Jurnal Manajemen Pendidikan, 6(1), 44-53. https://doi.org/10.24246/j.jk.2019.v6.i1.p44-53 